\title{
ANALYSIS OF FACTORS AFFECTING INCREASED TOURIST VISITS THAT HAVE AN IMPACT ON MSME DEVELOPMENT IMPLICATIONS FOR JOB CREATION AND REGIONAL REVENUE IN DKI JAKARTA
}

\author{
Taufiq Rachman \\ Borobudur University Postgraduate Program, Jakarta, Indonesia \\ Moh. Sidik Priadana \\ Borobudur University Postgraduate Program, Jakarta, Indonesia \\ Buchari Zainun \\ Borobudur University Postgraduate Program, Jakarta, Indonesia
}

\begin{abstract}
The purpose of this study was to determine and analyze the closeness of the relationship between tourism activities (security stability and macroeconomic policies, tourism policies and budgets, tourism development strategies, development strategies for resources and supporting infrastructure, length of stay improvement program) in DKI Jakarta. The research method is research carried out in DKI Jakarta in 2009. The research sample was obtained through proportional stratified random sampling with a total of 172 companies. This type of research is explanatory research which uses path analysis to explain the amount of direct and indirect contributions between variables. As a tool in statistical data processing, the SPSS Ver program is used. 16.00. The results showed that there was a significant relationship between the variables in economic activity. There is a very significant influence both partially and simultaneously between the variables of tourism activity on the increase in tourist visits between foreign and domestic tourists. There is a very significant influence both partially and simultaneously between the variable of increasing foreign and domestic tourist visits on the development of MSMEs. There is a very significant influence on the development of MSMEs in the tourism sector on job creation and regional revenue, respectively.
\end{abstract}

Key words: Tourists, UMKM Development, Regional Income. 
Cite this Article: Taufiq Rachman, Moh. Sidik Priadana and Buchari Zainun, Analysis of Factors Affecting Increased Tourist Visits that Have an Impact on MSME Development Implications for Job Creation and Regional Revenue in DKI Jakarta, International Journal of Management (IJM), 11(12), 2020, pp. 3314-3332.

http://iaeme.com/Home/issue/IJM?Volume=11\&Issue=12

\section{INTRODUCTION}

Indonesia is an archipelago located between the two continents of Asia and Australia. As an archipelago with more than 17,000 islands scattered from Sabang to Merauke, which has a variety of unique ethnicities and cultures, so that tourism potential is an attraction for tourists. Compared to other countries in Asean, Indonesia has such a large potential for natural tourism. However, tourist visits to Indonesia are much smaller compared to Malaysia, Singapore and Thailand. For example, according to a report issued by the World Tourism Organization in 1993, Indonesia only occupies the position of visiting foreign tourists at No. 22, while Malaysia is in the position of No. 16, Singapore is in the position of No. 18 and Thailand is in the position of No. 20 (Fazril, 2005).

Then according to the June edition of the UNWTO (United Nation World Tourism Organization) World Tourism Barometer, the first report for 2008 reported relatively stable international tourism visits. Despite the uncertainty in the global economy, international tourist arrivals experienced a growth of about 5\% between January and April 2008 compared to the same period in 2007.

According to Lindberg \& Hawkins (1993) in Fazril (2005), the main factors affecting the progress of tourism development are natural potential factors and infrastructure factors. According to Clark (1991) and Yoeti (1990) in Fazril (2005), the positive impact as a benefit from the development of the tourism sector, among others, increasing public income, employment, tax revenue, the stronger position of foreign payments, economic structure, government revenue, causing a multiplication effect.

The development of tourism development in tourism objects can be seen from the number of visitors, the length of stay of tourists in a tourist attraction, as well as tourist expenditure while in a tourist attraction (Mathieson \& Wall, 1996; Flecher, 1999 and Yoeti, 1990). With the development of the number of visits, length of stay, and expenditure of tourists in a tourism object, there will be positive impacts as a result of the development of tourism objects in the region, such as an increase in Regional Original Income (PAD).

The symptoms of tourism growth over the last two decades and qualitative changes in tourism structure are caused by various factors. These factors are the result of social, technological, economic, cultural and institutional changes. These factors are increased leisure time, technological development and urbanization, advancement of means of transportation, economic welfare, cultural factors and increased government attention. (Wahab, 2003, p. 32). In terms of additional free time, it was stated by Faurastie in Wahab (2003).

In 2008, Indonesia launched a tourism year "Visit Indonesia Year 2008" (VIY 2008) with the jargon "The Ultimate in Diversity". In 2007, Rp. 157 billion, of which $80 \%$ is only for the promotional budget for DTW throughout Indonesia (Antara, 2007). The number of tourist arrivals in Indonesia based on the results of data collection from 2000 to 2007 fluctuated from 4.5 million tourists to 5.5 million tourists per year.

The research objectives are to determine and analyze the closeness of the relationship between security stability variables and macroeconomic policies, tourism policies and budgets, tourism development strategies, development strategies for supporting facilities and infrastructure, programs for increasing length of stay and to determine and analyze the 
Analysis of Factors Affecting Increased Tourist Visits that Have an Impact on MSME

Development Implications for Job Creation and Regional Revenue in DKI Jakarta

magnitude of influence. partially and simultaneously from the variables of security stability and macroeconomic policies, tourism policies and budgets, tourism development strategies, development strategies for supporting facilities and infrastructure, programs to increase the length of stay for foreign tourist visits in DKI Jakarta.

\section{THEORETICAL BASIS}

\subsection{Development Theory}

In general, economic development is defined as a series of efforts in an economy to develop its economic activities so that infrastructure is more available, companies are more and more developing, the level of education is high and technology is increasing. As an implication of this development, it is hoped that job opportunities will increase, income levels will increase, and the prosperity of the community will be higher (Sadono Sukirno, 2006: p. 3).

According to the strict academic understanding of economics in Todaro (2000, p. 17) translated by Haris Munandar, the term development has traditionally been defined as the capacity of a national economy whose initial economic conditions were more or less static over a sufficient period of time. long to create and maintain the annual increase in its gross national income or GN P (Gross National Product).

According to Meiyer and Baldwi in Suryana (2000;3): Economics development is a process whereby an economy's real national income increases on a long period of time. And if the rate of development is greater than rate of population growth, then per capita real income will increase. Economic development is defined as a process that causes the per capita income of a society to increase in the long run. From this definition it contains three elements: (1) economic development as a process means continuous change which already contains elements of its own power for new investment; (2) efforts to increase per capita income; (3) the increase in per capita income must take place in the long term.

According to Todaro (2000, p. 21) the three core values of development are as follows:

Adequacy: the ability to meet basic needs Adequacy is not only about eating, but also represents all things that are the basic physical needs of humans. Basic needs include food, clothing, shelter, health and security. If even one of these basic needs is not met, then there arises a condition of absolute backwardness. The basic function of all economic activities is essentially to provide as much equipment and provisions as possible to avoid all misery and helplessness caused by lack of food, clothing, shelter, health and security.

Identity and envy: becoming a whole person Identity is the second universal component of an extravagant life, named the urge to progress, to respect oneself, to feel worthy and worthy of doing or pursuing something and so on.

Freedom from servitude: the ability to choose. Freedom or freedom should be broadly defined as the ability to stand upright so that it is not enslaved by the pursuit of material aspects of life. Freedom must also be interpreted as freedom from dogmatic teachings. If we see freedom, this means that we are forever able to think clearly and judge things on the basis of our own beliefs, firm thoughts, and conscience. Freedom also includes the ability of an individual or society to choose one or a part of the many available options.

Tourism according to Regional Regulation No. 10 of 2004 concerning Tourism is everything related to tourism, including the exploitation of tourism attractions and related businesses in that field. Tourism according to Law no. 10 of 2009 concerning Tourism is a variety of tourism activities and is supported by various facilities and services provided by the community, businessmen, government and local governments. 
Tourism Marketing according to Local Regulation No. 10 of 2004 concerning Tourism is an effort to introduce, promote and sell tourism products and destinations both domestically and abroad. Seaton and Benett (1996) identified 5 (five) important features of tourism marketing is:

- A consumer-oriented philosophy

- Analytical procedures and concepts

- Data collection technique

- Organizational structure

- Strategic decision areas and planning functions.

According to Wahab (2003: p. 9) tourism is an important factor to promote the unity of the nation and its people who have different regions, dialects, customs and tastes that are also diverse. Tourists according to Hunziker and Krapft in Nyoman S. Pendit (2006, p. 35) are a number of relationships and symptoms resulting from the stay of foreigners, as long as their stay does not lead to temporary housing and businesses. or permanently as a means of seeking full employment.

A tourist according to J. Christopher Holloway in Nyoman S. Pendit (2006, p. 33) is someone who goes on a trip to see something else and then complains when he pays something that is not appropriate.

\subsection{Tourism Activities}

According to Wahab (2003: p. 9) tourism activity is a two-way traffic. Each country must be a source country for tourists and also a tourist receiving country, although to varying degrees.

Tourism activities involve the actors, but absolutely must be taken into account, named (J. Damanik and HF Weber, 2006, p. 20):

- Tourists

- Tourism Industry

- Supporting Tourism Services

- Government

- Local Community

- Non-Governmental Organizations

\subsection{Tourism Budget Policy}

The most central thing to consider in making a travel decision is cost. Costs will determine the form, destination, travel time, type of lodging, transportation capital and other services used. What is the total allocation of costs that are available or need to be provided for the tourism activity to produce optimal results? What is the maximum expenditure in the tourist destination? These complicated considerations are often one of the reasons for choosing a tourist destination. For novice tourists, large costs can become a heavy burden, so the choice of destination is given to areas where local currency exchange rates are very low. Slightly different from that, experienced tourists prioritize satisfaction and total tourism experience as their main considerations. Therefore, the availability of accurate and up-to-date information about economic and financial developments in tourist destination areas is very important to make it easier for potential tourists to determine their travel costs. (Freyer, 1993 in J. Damanik and HF Weber, 2006, p. 6). 


\subsection{Tourism Object Development Strategy}

Strategy according to John Tribe (1997) in J. Damanik and HF Weber (2006, p. 39) is a master plan that has certain key characteristics. This is for the medium to long term and concerns goals, aiming at and hitting specific targets, planning for the desired future and designing appropriate ways to realize them.

\subsection{Tourism Support Facilities and Infrastructure}

Supporting facilities for tourism as follows (Wahab, 2003, p. 111):

\section{a. Means of attainment and supporting means of transportation}

Covers airports, seas for countries bordering multinational seas, rivers or lakes, railways and other land transportation, ships, air transport systems, mountain transportation and others.

\section{b. Complementary means}

These complementary means differ according to the state of development of a country. In general, these facilities include buildings that are a source of production of services which are quite important but absolutely not necessary for tourists. In general, these complementary facilities are recreational and entertainment in nature, such as: theater buildings, cinemas, casinos, night clubs, shops, drinking, coffee shops, clubs and others.

\subsection{Length of Stay Improvement Program}

Duration of traveling is a separate consideration. In this case the factor of availability of free time and money back plays an important role. Free time (the holiday season) is a determining factor for the size of the flow of tourists. In general, foreign tourists tend to be strict in regulating their travel time. Long before departure they have planned the trip, starting from the allocation of travel time, visits to tourist objects and attractions (ODTW), types of recreation to be carried out and so on. Just one day delay will pose a big risk to the entire tour agenda, starting from adding costs, arranging travel tickets, to adjusting the return schedule with various risks. Therefore, they are not tolerant of inappropriate timing in tourist destination areas. (J. Damanik and Weber, 2006, 9).

\section{Tourist Spending Fund Program}

An average tourist spends $+50 \%$ of his travel costs for hotel lodging and food purposes. The expenditure components consist of:

- $20 \%$ for entertainment and local transport.

- $10 \%$ for short visits (excursions).

- $10 \%$ for souvenir shopping.

- $10 \%$ for others.

This breakdown of fees applies more to travelers traveling alone than for groups of tourists and of course this can vary from country to country. (Wahab, 2003, p. 47).

\subsection{Economic Policy and MSME Development.}

According to Suryana (2000, p. 106), the macroeconomic policies can be made then adjustments are monetary policy and fiscal policy. 


\subsection{Contribution of MSMEs to Gross Domestic Product (GDP)}

From the aspect of GDP formation, in general, SMEs still provide a larger contribution than large businesses (Table 6). During the 2002-2005 period, the total role of SMEs was still above 50 percent, this shows that SMEs still have a very important role in creating added value. However, in a period of 3 years, there has been a decline in the role of SMEs in contributing to total GDP, this can be possible starting a shift from small businesses to shifting to medium enterprises and medium enterprises to shifting to large businesses. On small scale business from 40.62 percent in 2002 to 38.08 percent in 2005 and on the medium scale business from 16.54 percent to 16.13 percent. On the other hand, the role of large enterprises has increased from 42.84 percent in 2002 to 45.78 percent in 2005.

Related to the output aspect, Tambunan (2002) revealed that UKM also has a better level of competition than big business (UB), especially during the economic crisis. The share of output from large enterprises has continued to decline, from 62.0 percent in 1996 to 45.7 percent in 2000. A drastic decline occurred during the economic crisis, named 58.4 percent in 1997 to 49.8 percent in 1998. Meanwhile, the share of output of small businesses (UK) and medium enterprises (ME) increased respectively from 17.7 percent and 20.3 percent in 1996 to 29.0 percent and 25.3 percent in 2000.

The results of Djaimi's (2006) study on the role, behavior and performance of SMIs in the Indonesian economy with a comparison of the economic crisis (1998) and the post-economic crisis (2002) using the Social Accounting Matrix (SAM) model, the results of the study show that IKM has a big role in realizing high economic growth. Small industry has a greater contribution to gross output than medium and large industries. SMIs also have a gross output multiplier coefficient that is greater than large industries. The magnitude of the SME gross output multiplier coefficient is closely related to the magnitude of the multiplier coefficient of backward linkage, added value and labor production factors.

This indicates that it is appropriate for SMEs to get the main attention to realize economic development with high growth rates. Shin (2002) conducted a study on supply chain management for SMEs in ASIAN, particularly in Korea. SMEs play an important role in the Korean national economy, especially shown by the contribution of SMEs in terms of the employment share of 70 percent, the share of output of more than 40 percent, and the export volume of more than 42 percent. Furthermore Jung (2002) in his article states that South Korea has changed the direction of business development from an emphasis on large business groups (UB) to SMEs since 1999. This change in direction was carried out based on the fact that at the time of the economic crisis that hit South Korea since July 1997, a third of UB's in South Korea collapsed while MSMEs continued to grow and develop well. Since 1999, the contribution of MSMEs in the South Korean economy has shown a significant increase and is better than UB.

Abe and Kawakami (1997) conducted a study on the comparison of business sizes in Korea and Taiwan. They stated that the Korean government places more emphasis on developing UB (conglomerate business groups, chaebols), while the Taiwan government places more emphasis on developing MSMEs. Furthermore, Hall and Harvie (2003) conducted a study on the performance of MSMEs in Korea and Taiwan. Hall and Harvie stated that after the economic crisis, the Korean and Taiwanese governments put more emphasis on developing MSMEs to improve their economies.

\subsection{Additional Number of Tourist Visits}

Tourists in the tourism demand segmentation have various motives, interests, expectations, social, economic, cultural characteristics and so on. (Steck, et al., 1999 and Heher, 2003 in J. Damanik and HF Weber, 2006, p. 19). With different motives and backgrounds, they are the ones who create demand for tourism products and services. This role is very decisive and is 
often positioned at the heart of tourism activities itself. Therefore, many other actors depend on and in some cases even submit to it.

Important elements in tourism demand are tourists and local residents who use the resources (tourism products and services). Its main basis is the availability of time and money in the group. (Kelly, 1998 and Gunn, 2002 in J. Damanik and HF Weber, 2006, p. 3). With the time and resource they have, they are the main consumers who consume tourism products and services provided in the country or tourist destination.

Another factor plays a role is the easier accessibility to products and tourist attractions. Therefore, there must be a medium that connects tourists with these products, named access, in this case in the form of transportation infrastructure. Besides that, travel is also influenced by various other factors such as distribution and increase in income and community education, reduction of working hours, climate and environment. (Freyer, 1993, and Mundt, 1998 in J. Damanik and HF Weber, 2006, p. 3).

Another variable is time availability. In many regions, 5 working days per week have been applied. This means that the remaining two days off become free time that can be used for vacation. The need for tourism is closely related to climate problems and environmental conditions at high altitudes. Usually people who live in hot areas have the need to find a place with a cool climate and minimal levels of environmental pollution.

\subsection{Regional Revenue}

In the relationship between the central and local governments, Davey (1988: p. 25-35) suggests that local government funding consists of allocations from the central government, taxation and business entities. In the perspective of autonomy, PAD is the main source of finance besides other types of regional revenue.

Regional revenues are all regional cash receipts within a certain fiscal year. (Widjaja, 2002: p. 148). Basically, local revenue sources consist of:

- Regional Original Income (PAD)

- Balancing Fund

- Regional Loans

- Other valid receipts.

PAD consists of taxes, levies, proceeds from regional-owned companies and the proceeds from the management of regional assets such as a share of profits, dividends and sales of shares owned by the region and other loans (Widjaja, 2002, p. 110).

State revenue from the United Nations is divided by a balance of $10 \%$ for the Government and $90 \%$ for the Regions. State revenue from BPHATB is divided by a balance of $20 \%$ for the Government and $80 \%$ for the Regions. Ten percent (10\%) of PBB revenue and $20 \%$ of BPHATB revenue which is part of the Government are distributed to all Regencies and Cities that he tours in a Government Regulation.

\subsection{Tourism Employment}

Tourism is a multiproduct industry where the overall tourist experience is created by the product mix. (Diamond, 1977 in F. Vellas and L. Becherel, 2008, p. 206). Accommodation, restaurants and attractions are some of the products that can be mentioned. From this fact, tourism employment includes jobs in various sectors such as accommodation, restaurants, attractions, airlines, souvenir shops, travel agencies and travel agents, transportation, and so on. Different sectors are associated with a wide range of employment with varying human resource requirements. 
Tourism jobs are available in a number of industries, such as agriculture, retail, passenger transport, business services and local government, which in turn broadens the diversity of employment opportunities that tourism offers. (Messenger, 1991 in F. Vellas and L. Becherel, 2008, 207).

\subsection{Competitiveness of the Tourism Sector}

According to Porter (1994: 1), competition is the essence of success or failure. Competition determines the appropriateness of organizational activities that can support performance such as innovation, a cohesive culture or good practice. Competitive strategy is the search for a favorable competitive position in an industry, the fundamental arena in which competition occurs. Competitive strategy aims to establish a favorable and defensible position against the forces that determine industrial competition.

The definition of competitiveness at the national level is the degree to which a country, in free and fair market conditions, produce goods and services that meet international market tests while simultaneously increasing the real income of its citizens. Competitiveness at the national level is based on superior productivity performance. (The Presidential Competitiveness Commission Report, written for the Reagan administration in 1984 in Dong-Sung Cho and Hwy-Chang Moon, 2003; 246)

According to Porter $(1994 ; 4)$, in any industry, both domestically and internationally or producing products or services, competition rules include 5 (five) competitive forces, named:

- The entry of new competitors.

- Threats from substitute products (substitutes).

- The bargaining power of the buyer.

- The power supply of suppliers.

- Competition is among existing competitors.

\section{METHOD}

The research method used is a survey method. Data collection for primary data was obtained from distributing questionnaires to respondents obtained from the DKI Jakarta Tourism Office, the Indonesian Tour \& Travel Association (ASITA), the Indonesian Hotel and Restaurant Entrepreneurs Association (APHRI). The population in this study were 350 tourism sector companies, consisting of 120 travel agents, 70 hotels and 160 restaurants. The sampling technique used in primary data collection (questionnaires) is sectionals stratified random sampling, which is a sampling technique used when the population has members or elements that are not homogeneous and proportionally stratified. (Sugiyono, 2005, p. 75). According to Uma Sekaran (2006, p. 132), this sampling design is more efficient than a simple random sampling design, because for the same sample size, each important segment of the population is better represented, and the information obtained is more valuable and diverse related to each group. Based on Isaac and Michael with sectionals stratified random sampling, the number of respondents specified in the study were 175 respondents representing large, medium and small companies. But the data collected was only 172 respondents (3 respondents, the data obtained were deemed ineligible / disabled / damaged) While the secondary data used for descriptive analysis were collected in complete sequence (time series) from 1988 to 2007 which were obtained from the Tourism Office. DKI Jakarta, Indonesian Tour \& Travel Association (ASITA), Indonesian Hotel and Restaurant Entrepreneurs Association (APHRI), DKI Jakarta Central Statistics Agency (BPS), KADIN Jakarta and DKI Jakarta Manpower Office. Descriptive analysis is used to make systematic, factual and accurate descriptions, descriptions 
or paintings of the facts, properties and relationships between the phenomena being investigated.

\subsection{Research Variables}

The variables used in the research are: Security Stability Variable and Macroeconomic Policy, Tourism Policy and Budget, Tourism Development Strategy, Development Strategy for Supporting Facilities and Infrastructure, Program for Increasing Length of Stay, Increasing Foreign Tourist Visits, Increasing Indonesian Tourist Visits, Development of Sector MSMEs. Tourism, Tourism Job Creation, and Increasing Regional Revenue from the Tourism Sector in DKI Jakarta. details of the research path equation, can be explained in detail, as follows:

\subsubsection{The structure of the first model}

$$
\begin{aligned}
& \mathrm{Y} 1=\mathrm{f}(\mathrm{X} 1, \mathrm{X} 2, \mathrm{X} 3, \mathrm{X} 4, \mathrm{X} 5) \\
& \mathrm{Y} 1=\rho \mathrm{Y} 1 \mathrm{X} 1 \mathrm{X} 1+\rho \mathrm{Y} 1 \mathrm{X} 2 \mathrm{X} 2+\rho \mathrm{Y} 1 \mathrm{X} 3 \mathrm{X} 3+\rho \mathrm{Y} 1 \mathrm{X} 4 \mathrm{X} 4+\rho \mathrm{Y} 1 \mathrm{X} 5 \mathrm{X} 5+\epsilon 1
\end{aligned}
$$

Where:

Y $1=$ Increase in foreign tourist visits

$\mathrm{X} 1$ = Security stability and Macroeconomic policies

$\mathrm{X} 2$ = Tourism Policy and Budget

X 3 = Tourist Attraction Development Strategy

X 4 = Support Infrastructure Development Strategy

$\mathrm{X} 5$ = Length of Stay Improvement Program

$\rho Y 1 X i=$ path coefficient of the independent variable on the dependent variable

$\epsilon 1=$ Effect of other variables outside the model

\subsubsection{The structure of the second model}

$$
\begin{aligned}
& \mathrm{Y} 2=\mathrm{f}(\mathrm{X} 1, \mathrm{X} 2, \mathrm{X} 3, \mathrm{X} 4, \mathrm{X} 5) \\
& \mathrm{Y} 2=\rho \mathrm{Y} 2 \mathrm{X} 1 \mathrm{X} 1+\rho \mathrm{Y} 2 \mathrm{X} 2 \mathrm{X} 2+\rho \mathrm{Y} 2 \mathrm{X} 3 \mathrm{X} 3+\rho \mathrm{Y} 2 \mathrm{X} 4 \mathrm{X} 4+\rho \mathrm{Y} 2 \mathrm{X} 5 \mathrm{X} 5+\epsilon 2
\end{aligned}
$$

Where:

Y 2 = Increasing tourist visits to the archipelago

$\mathrm{X} 1$ = Security Stability and Macroeconomic policies

$\mathrm{X} 2$ = Tourism Policy and Budget

X 3 = Tourism Object Development Strategy

X 4= Support Infrastructure Development Strategy

$\mathrm{X} 5$ = Length of Stay Improvement Program

$\rho Y 2 X i=$ coefficient of independent variable path towards variable 1 bound

$€ 2=$ The effect of other variables outside the model

\subsubsection{The structure of the third model}

$$
\begin{aligned}
& \mathrm{Z} 1=\mathrm{f}(\mathrm{Y} 1, \mathrm{Y} 2) \\
& \mathrm{Z} 1=\rho \mathrm{Z} 1 \mathrm{Y} 1 \mathrm{Y} 1+\rho \mathrm{Z} 1 \mathrm{Y} 2 \mathrm{Y} 2+\mathrm{C} 3
\end{aligned}
$$

Where:

Z 1 = MSME development in the tourism sector

$\rho \mathrm{Z1Yi}=$ Coefficient of the independent variable's pathway to the dependent variable

€ 3 = The effect of other variables outside the model 


\subsubsection{The structure of the fourth model}

$\mathrm{Z} 2=\mathrm{f}(\mathrm{Z} 1)$

$Z 2=\rho Z 2 Z 1 \quad Z 1+C 4$

Where:

$\mathrm{Z} 2$ = Tourism Job Creation or,

$\rho \mathrm{Z1Yi}=$ path coefficient of the independent variable on the dependent variable

$€ 4=$ Effect of other variables outside the model

\subsubsection{The structure of the fifth model:}

$$
\begin{aligned}
& Z 3=f(Z 1) \\
& Z 3=\rho Z 3 Z 1 \quad Z 1+C 5
\end{aligned}
$$

Where:

Z 3 = Increase in Regional Revenue from the Tourism Sector

$\rho \mathrm{Z} 3 \mathrm{Z1}=$ path coefficient of the independent variable on the dependent variable

$\epsilon 5=$ The effect of other variables outside the model

In data analysis, the technique used is descriptive analysis technique and path analysis. Path analysis (path Analysis) to be used in examining the contribution (contribution) indicated by the path coefficient for each path diagram of the causal relationship between independent variables and the dependent. Correlation and regression analysis are the basis for calculating the path coefficient. (Riduwan and Kuncoro: 2007, p. 115). According to Al Rasyid and Sitepu (1994) it is stated that social research does not merely reveal variable relationships as a statistical translation of natural variable relationship, but focuses on efforts to reveal variable causal relationships. Path analysis data were obtained from perceptions based on distributing questionnaires to respondents.

\subsubsection{Hypothesis Testing}

The statistical tests that will be used in this research include:

Parametric test of the $\mathrm{F}$ value

According to Kuncoro (2003: p. 219), the F statistical test basically shows whether all the independent variables included in the model have a joint influence on the dependent variable. The null hypothesis ( Ho ) to be tested is whether all the parameters in the model are equal to zero, or:

$$
\mathrm{Ho}: \mathrm{b} 1=\mathrm{b} 2=\ldots \ldots . .=\mathrm{b} \mathrm{k}=0
$$

That is, whether an independent variable is not a significant explanation for the dependent variable. The alternative hypothesis $(\mathrm{H} \mathrm{a})$, not all parameters are simultaneously equal to zero, or:

$$
\mathrm{H} \mathrm{a}: \text { b } 1 \square \text { b } 2 \square \quad \ldots . \square \text { bk } \square 0
$$

That is, all independent variables are simultaneously significant explanations of the dependent variable.

To test these two hypotheses, the F statistic is used. F statistical value is calculated from the following formula:

$\mathrm{F}=\mathrm{MSR}=\mathrm{SSR} / \mathrm{k}$

MSE SSE / (nk) 
Where:

$\mathrm{SSR}=$ sum of square due to regression $=\square(\mathrm{Y} \mathrm{i}-\mathrm{y}) 2$

$\wedge$

$\mathrm{SSE}=$ sum of square error $=\square(\mathrm{Y} \mathrm{i}-\mathrm{Y}$ i $) 2$

$\mathrm{n}=$ number of observations

$\mathrm{k}=$ number of parameters (including intercept) in the model

$\mathrm{MSR}=$ mean square due to regression

MSE = mean of square due to error

Basically, the F value is derived from the ANOVA (Analysis of Variance) table. Remember that TSS $=$ SSR + SSE, meaning that the total sum of square (TSS) comes from the regression variation (SSR) and error variation (SSE), which is divided by the respective degrees of freedom.

Parametric test of the $t$ value

The $t$ test according to Nachrowi and Hardius Usman (2002: p. 25) is a test that aims to determine whether the regression coefficient is significant or not. Before conducting the test, a hypothesis is usually made, which for the t-test usually takes the form:

H 0: $\square=0$ : There is no influence of independent variables

against dependent.

H 1: $\square \square 0$ : There is an effect of independent variables

against dependent.

Meaning:

Based on the available data, the population regression coefficient will be tested, whether it is equal to zero, which means that it has no significant influence on the dependent variable, or is not equal to zero which means it has a significant effect.

\section{RESULTS AND DISCUSSION}

\subsection{Discussion of Inductive Analysis}

\subsubsection{The structure of the path analysis model in research.}

The variables that influence tourist visits consist of: security stability and macroeconomic policies (X 1 ), tourism policies and budgets (X 2 ), tourism development strategies (X 3 ), supporting facilities and infrastructure development strategies (X 4 ), and length of stay improvement program (X 5 ). The variables of increasing foreign tourist visits (Y 1 ), increasing domestic tourist visits (Y 2 ), developing MSMEs in the tourism sector (Z 1$)$, creating jobs ( $\mathrm{Z}$ 2 ), increasing regional revenues from the tourism sector ( $Z 3)$ are the intermediate variable (intervening variables). For more details, it can be explained as follows:

- Model structure 1; The model that relates the relationship between the relationship and the influence of the nine independent variables ( X 1, X 2, X 3, X 4, X 5 ) on the Y1 variable with the amount of influence of other variables outside the model of $\varepsilon 1$.

- Model 2 structure; The model hook inter-relationship and influence between ninth independent variable ( $\mathrm{X} 1 \mathrm{x} 2 \mathrm{X} 3 \mathrm{X} 4 \mathrm{X} 5)$ to variable $\mathrm{Y} 2$ with the amount of influence variable other than a model of $\varepsilon 2$. 
- Model 3 structure; The model hooks inter-relationship and Oversight of the spirit between the two independent variables

$(\mathrm{Y} 1$, and $\mathrm{Y} 2$ ) to variable $\mathrm{Z} 1$ with influence another magnitude variable outside the model of $\varepsilon 3$.

- Model structure 4; The model that links the relationship between the relationship and the influence between the independent variable $\mathrm{Z1} \mathrm{t}$ on the $\mathrm{Z} 2$ variable with the magnitude of the influence of other variables outside the model is $\varepsilon 4$.

- Model 5 structure; The model that relates the relationship between the relationship and the influence between the independent variable $\mathrm{Z} 2$ on the $\mathrm{Z} 3$ variable with the magnitude of the influence of other variables outside the model of $\varepsilon 5$.

\subsubsection{Analysis of the Relationship Between Independent Variables}

\subsubsection{For Structure Model 1 and Structure Model 2}

Because the independent variables of the structure of model 1 are the same as the structure of model 2, then based on the results of the correlation analysis from the path analysis between the five independent variables, there is a positive relationship between the variables of Security Stability and Macroeconomic policies (X 1 ), Tourism Policy and Budget (X 2 ), the spirit of the Tourism Object Development Strategy (X 3 ), the Supporting Infrastructure Development Strategy (X 4 ), the Length of Stay Improvement Program ( X 5 ). Thus, from the results of the analysis of the correlation coefficient between the five independent variables, it can be concluded that all of the independent variables have a relationship with each other, with the lowest closeness of the relationship of 0.097 (X 1 with X 3 ), while the highest closeness of the relationship is 0.371 (X 2 with .X 5 ).

This is understandable, considering that the Program for Increasing the Length of Stay will be closely related to the extent to which the tourism policies and budgets are carried out by the government and by the entrepreneurs themselves.

Of the five independent variables mentioned above, it indicates that there is a relationship with each other, this is a unit that cannot be separated. Therefore, in an effort to optimize the increase in foreign tourist visits ( $\mathrm{Y} 1$ ) and increase in domestic tourist visits ( $\mathrm{Y} 2$ ), it is necessary to pay attention to these five variables. However, apart from the five variables mentioned above, the government, companies and employees themselves pay attention to other variables outside the established model, including; Aspects of support / facilities in building partnerships, the existence of regulatory support and ease of investment licensing, and development of education and training, as well as development of researches in the tourism sector, etc.

\subsubsection{For Structure Model 3}

Based on the results of the correlation analysis from the path analysis between the two independent variables for the Model 3 structure, there is a positive relationship between the variables of foreign tourist visits ( $\mathrm{Y} 1$ ) and the increase in domestic tourist visits (Y 2$)$, thus, the results of the analysis of the magnitude of the correlation coefficient between the two independent variables, it can be concluded that the two independent variables have a relationship with each other, with a closeness of the relationship of 0.387 .

\subsubsection{For Structure Model 4 and Structure Model 5}

In both the structure of model 4 and model 5 there is no correlational relationship, considering that the model structure only consists of one variable. 
Analysis of Factors Affecting Increased Tourist Visits that Have an Impact on MSME

Development Implications for Job Creation and Regional Revenue in DKI Jakarta

\subsubsection{Influence analysis among independent variables with dependent}

\subsubsection{Analysis of the influence of variables on the model structure 1}

As it is known that the influence of the independent variable $(\mathrm{X})$ on the dependent variable $(\mathrm{Y})$, there are two forms, named partial influence and simultaneous influence. Therefore, the discussion will be divided into two parts:

Partial Influence.

Based on the results of the calculation of the path analysis and the results of partial hypothesis testing of the influence of the variables of Security Stability and Macroeconomic policies (X 1 ), Tourism Policy and Budget (X 2 ), the spirit of the Tourism Object Development Strategy (X 3 ) , the Supporting Infrastructure Development Strategy ( X 4 ), Length of Stay Improvement Program (X 5 ). to Increased Foreign tourist arrivals (Y 1 ), it can be concluded that kelma independent variable $(X)$ are in each - each have a significant influence, (the sum of the amount of direct influence and indirect effect). The magnitude of the influence of the independent variables, then the variable Security Stability and Macroeconomic policies are the variables that have the greatest influence on the increase in foreign tourist visits.

This can be understood because security stability and macroeconomic policies are the main factors that become prerequisite and motivating factors for people to do tourism activities and visit Indonesia, especially DKI Jakarta.

The variable that has the smallest effect is the variable length of stay improvement program, this is understandable considering the length of stay increase program is a complementary factor only in efforts to increase tourism.

The order of the magnitude of the influence of the independent variable on the dependent variable can be seen in Table 1 as follows:

Table 1 Direct and indirect effect of variable X on Y 1

\begin{tabular}{|l|lll|l|}
\hline Variable & $\begin{array}{l}\text { Total } \\
\text { Direct } \\
\text { Effects }\end{array}$ & $\begin{array}{l}\text { Total } \\
\text { Indirect } \\
\text { Effects }\end{array}$ & $\begin{array}{l}\text { Effects } \\
\text { Rank }\end{array}$ \\
\hline $\mathrm{X} 1$ & 0.277 & 0.062 & 0.338 & First \\
\hline $\mathrm{X} 2$ & 0.032 & 0.036 & 0.068 & Fourth \\
\hline $\mathrm{X} 3$ & 0.187 & 0.072 & 0.259 & Second \\
\hline $\mathrm{X} 4$ & 0.061 & 0.045 & 0.106 & Third \\
\hline $\mathrm{X} 5$ & 0.018 & 0.043 & 0.061 & Fifth \\
\hline
\end{tabular}

Simultaneous influence.

Based on the results of the path analysis and the results of hypothesis testing for the joint influence of the variable influence of Security Stability and Macroeconomic policies (X 1 ), Tourism Policy and Budget (X 2 ), the spirit of the Tourism Object Development Strategy (X 3 ), the Supporting Infrastructure Development Strategy ( X 4 ), Length of Stay Improvement Program (X 5 ), it can be concluded that the five independent variables have a high enough / strong enough influence with the magnitude of the influence of $83.30 \%$. Thus, if the five variables are improved, the Improvement of Work Ethic Quality can develop optimally.

\subsubsection{Analysis of the influence of variables on the model structure 2}

As it is known that the influence of the independent variable $(\mathrm{X})$ on the dependent variable $(\mathrm{Y})$, there are two forms, named partial influence and simultaneous influence. Therefore, the discussion will be divided into two parts: 
Partial Influence.

Based on the results of path analysis calculations and partial hypothesis testing results from the influence of the variable Security Stability and Macroeconomic policies (X 1 ), Tourism Policy and Budget (X 2 ), the spirit of the Tourism Object Development Strategy (X 3 ), the Supporting Infrastructure Development Strategy ( X 4 ), the Program for Increasing the Length of Stay (X 5 ) on the Increase in Indonesian tourist visits (Y 2 ), it can be concluded that the five independent variables $(\mathrm{X})$ each have a significant effect, (the sum of the magnitude of the direct and indirect effects. live). The magnitude of the influence of these independent variables, then the variables of Security Stability and Macroeconomic policies are the variables that have the greatest influence on the increase in foreign tourist visits.

This can be understood because security stability and macroeconomic policies are the main factors that become prerequisite and motivating factors for people to do tourism activities and visit DKI Jakarta.

The variable that has the smallest effect is the variable length of stay improvement program, this is understandable considering the length of stay increase program is a complementary factor only in efforts to increase tourism.

The order of the magnitude of the influence of the independent variable on the dependent variable can be seen in Table 2 as follows:

Table 2 Direct and indirect effect of variable X on Y 2

\begin{tabular}{|c|c|c|c|c|}
\hline Variable & $\begin{array}{c}\text { Direct } \\
\text { Influence }\end{array}$ & $\begin{array}{c}\text { Total } \\
\text { Indirect } \\
\text { Influence }\end{array}$ & $\begin{array}{c}\text { Total } \\
\text { Influence }\end{array}$ & $\begin{array}{c}\text { Influence } \\
\text { Rank }\end{array}$ \\
\hline X1 & 0.277 & 0.067 & 0.328 & First \\
\hline X2 & 0.032 & 0.040 & 0.082 & Fourth \\
\hline X3 & 0.187 & 0.092 & 0.282 & Second \\
\hline X4 & 0.061 & 0.059 & 0.110 & Third \\
\hline X5 & 0.018 & 0.044 & 0.072 & fifth \\
\hline
\end{tabular}

Simultaneous influence.

Based on the results of the path analysis and the results of hypothesis testing for the joint influence of the variable Security Stability and Macroeconomic policies (X 1 ), Tourism Policy and Budget (X 2 ), the spirit of the Tourism Object Development Strategy (X 3 ), the Supporting Infrastructure Development Strategy (X 4 ), Program for Increasing the Length of Stay (X 5 ) on the increase in tourist visits to the archipelago (Y 2 ), it can be concluded that the five independent variables have a high enough / strong enough influence with the magnitude of the influence of $87.40 \%$. Thus, if the five variables are increased, the increase in tourist visits in the archipelago can increase optimally.

\subsubsection{Analysis of the influence of variables on the model structure 3}

As it is known that the influence of the independent variable $(\mathrm{Y})$ on the dependent variable $(\mathrm{Z}$ 1 ), there are two forms, named partial influence and simultaneous influence. Therefore the, discussion will be divided into two parts: 
Analysis of Factors Affecting Increased Tourist Visits that Have an Impact on MSME

Development Implications for Job Creation and Regional Revenue in DKI Jakarta

Partial Influence.

Based on the results of the path analysis calculations and the partial hypothesis testing results from the influence of the variable increase in foreign tourist visits (Y 1 ) and the increase in domestic tourist visits (Y 2 ), on the development of MSMEs in the tourism sector (Z 1 ), it can be concluded that the two independent variables ( Y 1 and Y 2 ) respectively have a significant effect, (the sum of the direct and indirect effects). The magnitude of the influence of the independent variable, then the increase in the number and spending of domestic tourists is the variable that has the greatest influence on the development of MSMEs in the tourism sector. This can be understood because the increase in the number and spending of domestic tourists is the main factor that represents the amount of contribution to the number of tours and the number of business transactions and purchases of goods, etc., thus increasing demand for various services and products that tourists need. Meanwhile, the variable of increasing the number and spending of foreign tourists is a supporting or additional variable to further increase and increase business activities and income for the tourism sector MSMEs. $H$ al is understandable given tourism or tourists who come to Jakarta quite the number of tourists coming and consists of various layers of society, from the richest strata of society to the bottom layer of the Community. Once the interests of tourists who come to Jakarta are very varied, starting from combining work interests combined with tourism interests both for themselves and their families. Likewise, other communities always combine various interests or activities.

The sequence of the contribution the influence of independent variables on the dependent variable, can be seen in T abel 3 as follows:

Table 3 Direct and indirect effect of variable $\mathrm{Y}$ on $\mathrm{Z1}$

\begin{tabular}{|c|c|c|c|c|}
\hline Variable & Direct Influence & $\begin{array}{c}\text { Total Indirect } \\
\text { Influence }\end{array}$ & $\begin{array}{c}\text { Total } \\
\text { Influence }\end{array}$ & $\begin{array}{c}\text { Influence } \\
\text { Rank }\end{array}$ \\
\hline Y2 & 0.400 & 0.123 & 0.523 & First \\
\hline Y1 & 0.251 & 0.123 & 0.374 & Second \\
\hline
\end{tabular}

Simultaneous influence.

Based on the results of the path analysis and hypothesis testing results for the joint effect of increasing foreign tourist visits (Y 1 ) and increasing domestic tourist visits (Y 2 ) on the development of MSMEs in the tourism sector ( $\mathrm{Z} 1$ ), it can be concluded that the two independent variables have a significant influence high enough / strong enough with a magnitude of influence of $89.70 \%$. Thus, if the two variables are increased, the development of MSMEs in the tourism sector can develop optimally.

\subsubsection{Analysis of the influence of variables on the model structure 4}

Based on the results of the path analysis calculations and the results of testing the hypothesis of the influence of the tourism sector MSME Development variable ( $\mathrm{Z} 1$ ) on Tourism Job Creation (Z 2 ), it can be concluded that the independent variable has a significant effect, with the magnitude of the influence of $95.70 \%$. It can be concluded that the independent variable has a high enough / strong enough influence. Thus, if these variables are increased, job creation from the tourism sector, both those who work directly in the tourism sector, and those who work in the tourism supporting sector can increase optimally. 


\subsubsection{Analysis of the influence of variables on the model structure 5}

Based on the results of the calculation of the path analysis and the results of testing the hypothesis of the influence of the Tourism Job Creation variable $(Z 2)$ on the Increase in Regional Revenue from the Tourism Sector (Z 3 ), it can be concluded that the independent variable has a significant effect, with the magnitude of the influence of $93,20 \%$, it can be concluded that the independent variable has a high enough influence. Thus, if these variables are increased, the increase in regional revenue from the tourism sector, both direct revenue from taxes and levies from the tourism sector, as well as indirect revenues or taxes and levies from the tourism supporting sector, can increase optimally.

\section{CONCLUSION}

Based on the results of the analysis and discussion, several things can be concluded as follows:

- There is a meaningful relationship between the variables of Security Stability and Macroeconomic Policy, Tourism Policy and Budget, Tourism Development Strategy, Tourism Support Facilities and Infrastructure Development Strategy, Length of Stay Improvement Program. The lowest closeness of the relationship is the variable of Security Stability and Macroeconomic Policy with the variable of Tourism Object Development Strategy, while the highest closeness of the relationship is the variable of Macroeconomic Security and Policy, Policy with the variable of Length of Stay Improvement Program.

- There is an influence both partially and simultaneously of the variables of Security Stability and Macroeconomic policies, Tourism Policies and Budgets, Tourism Object Development Strategies, Supporting Facilities and Infrastructure Development Strategies, Length of Stay Improvement Programs on Increasing the Number and Expenditures of Foreign Tourists in DKI Jakarta is very significant. The biggest influence is Security Stability and Macroeconomic policies, while the one with the smallest effect is the Length of Stay Improvement Program

- There is an influence both partially and simultaneously of the variables of Security Stability and Macroeconomic policies, Tourism Policies and Budgets, Tourism Object Development Strategies, Supporting Facilities and Infrastructure Development Strategies, Length of Stay Improvement Programs on Increasing the Number and Expenditures of domestic tourists in Indonesia. DKI Jakarta is very significant. The biggest influence is Security Stability and Macroeconomic policies, while the one with the smallest effect is the Length of Stay Improvement Program.

- There is an influence both partially and simultaneously of the variables of the Increase in the Amount and Expenditure of Foreign Tourists and the Variable of Increasing the Amount and Expenditures of Indonesian Tourists on the Development of MSME Business in the Tourism Sector in DKI Jakarta is very significant. The biggest influence is the increase in the number and spending of domestic tourists, which is the variable that has the greatest influence on the development of MSMEs in the tourism sector.

- There is a very significant influence of MSME Business Development in the Tourism sector on Job Creation in the Tourism Sector in DKI Jakarta. Thus, if the tourism sector MSME Business Development variable increases, then job creation from the tourism sector will increase, both those working directly in the tourism sector and those working in the tourism supporting sector can increase optimally.

- There is a very significant effect of job creation in the tourism sector on the increase in regional revenue from the tourism sector in DKI Jakarta. Thus, if the variable of job creation in the tourism sector increases, the increase in regional revenue from the 
Analysis of Factors Affecting Increased Tourist Visits that Have an Impact on MSME

Development Implications for Job Creation and Regional Revenue in DKI Jakarta

tourism sector, both direct revenue from taxes and levies from the tourism sector, as well as indirect revenue or taxes and levies from the tourism supporting sector can increase optimally.

\section{REFERENCES}

[1] Central Bureau of Statistics for DKI Jakarta 2006 \& 2007 , Economic Statistics of Indonesia, Jakarta-Indonesia.

[2] Central Bureau of Statistics (BPS), 2006. Jakarta in Figures . BPS Catalog. 1403.31. Jakarta.

[3] Central Bureau of Statistics (BPS), 2006. Statistical Year Book of Indonesia . BPS Catalog. 1401. Jakarta.

[4] Central Statistics Agency (BPS), 2006. Statistics 60 Years of Independent Indonesia . BPS Catalog. 1187. Jakarta.

[5] Central Bureau of Statistics (BPS), 2007. Official Statistic News . No. 38/07 / Th. X, 2 July 2007. Jakarta.

[6] Baldwin RE Meiyer. 1981. Development and Economic Growth in Developing Countries . Bina Aksara, Jakarta.

[7] Guidebook. Dissertation Writing of the Borobudur University Postgraduate Doctoral Program. 2003.

[8] Cole, Stroma. 1997. Cultural Heritage Tourism. The Villagers's Prespective: A Case Srudy from Ngada, Flores . In Nuryanti (ed). Tourism and Heritage Management. Gadjah Mada University Press. Yogyakarta.

[9] Damanik, Janianton and Weber, Helmut F. 2006. Ecotourism Planning. From Theory to Application . Center for Tourism Studies (Puspar) UGM and Publisher Andi, Yogyakarta.

[10] Dong-Sung Cho and Hwy-Chang Moon, 2003. From Adam Smith to Michael Porter. The Evolution of Competitiveness Theory . Translator: Erly Suandy. Publisher Salemba Empat, Jakarta.

[11] Faurastie, Jean, 1967. Reflexions Prospectives Sur La Civilization des Loisirs, La Civilization des Loisirs . Marabout Universitie.

[12] Fazril, 2005. The Influence of Components of Lake Tourism Products on the Number of Visits, Length of Stay and the Amount of Tourist Expenditures and the Impact on Local Revenue in West Sumatra Province . Journal of Economics, University of Borobudur Volume 17 February 2005. Faculty of Economics, University of Borobudur, Jakarta.

[13] Henderson, Joan. 2002. Creating Experiences for Our Visitor: Tourist Guide Licensing and Training in Singapore. Volume 1, Number 2, July 2002. ASEAN Journal and Hospitality and Tourism and Nanyang Technological University, Singapore.

[14] Kauh Ah Keng. 1998. Assessing Macro Environment Trends in Singapore: Implications for Tourism Marketers . Asia Pacific Journal of Tourism and National University of Singapore.

[15] Kuncoro, Mudrajad. 2004. Quantitative Methods. Theory and Applications for Business and Economics . Second Edition. UPP AMP YKPN, Yogyakarta.

[16] Kusmayadi and Endar Sugiarto, 2000. Research Methodology in the Tourism Sector . PT. Gramedia Pustaka Utama, Jakarta. 
[17] Lumsdon, L. 1997. Tourism Marketing . International Thompson Business Press: London.

[18] Martana, Salmon Priaji. 2002. The Impact of Tourism on the Development of Ubud Painting Art . Volume 1, Number 2, July 2002. ASEAN Journal on Hispitality and Tourism and Center for Tourism Research, Bandung Institute of Technology.

[19] Mills, Allan. 2002. Tourism Survey Research . Volume 1, Number 2, July 2002. ASEAN Journal on Hispitality and Tourism and Virgnia Commonwealth University, USA.

[20] Nachrowi, et al. 2005. Use of Econometric Techniques . Revised Edition. PT. Raja Grafindo Persada, Jakarta.

[21] Nafziger, EW 1997. The Economics of Developing Countries. Third Edition. Upper Saddle River, New Jersey.

[22] Pendit, Nyoman S. 2006. Tourism Science . Pradnya Paramita. Jakarta.

[23] Porter, ME 1994. Competitive Advantage. Creating and Maintaining Superior Performance . Binarupa Aksara, Jakarta.

[24] Pratisto, Arif. 2004. Easy Ways to Solve Problems in Statistics and Experimental Design with SPSS 12 . PT. Elex Media Komputindo Gramedia Group. Jakarta.

[25] Prawirokusumo, S. 2001. People's Economy. (Concepts, Policies and Strategies) . First Edition. BPFE, Yogyakarta.

[26] Prodeaux, Bruce and Malcolm Cooper. 2002. Ecotourism in Indonesia: A Strategy for Regional Tourism Development . Volume 1, Number 2, July 2002. ASEAN Journal on Hispitality and Tourism and The University of Queensland, Australia.

[27] Rahmanita, Myrza. 2001. The Potential of Cirebon Tourism Development as a Heritage Tourism Destination . Bournemouth University, England. ( unpublished ).

[28] Rahmanita, Myrza. 2002. Tourism Certification Programs: Can They Bring About Sustainable Tourism? Case Study of Bournemouth, England-Green Globe 21 at a Glance . Dissertation. Bournemouth University, England. ( unpublished ).

[29] Riduwan and Kuncoro, EA 2007. How to Use and Interpret Path Analysis . Alfabeta, Bandung.

[30] Now, Uma. 2006. Research Methods for Business. Research Methodology for Business . Translator: Kwan Men Yon. Publisher Salemba Empat, Jakarta.

[31] Seaton, AV and Benett, MM 1996. The Marketing Tourism Products: Concepts, Issues and Cases . International Thompson Business Press: London.

[32] Silver, Christopher. 2002. Tourism and Local Economic Development in the Era of Indonesia's Decentralization. Volume 1, Number 2, July 2002. ASEAN Journal on Hispitality and Tourism and University of Illionis at Urbana-Champaign, USA.

[33] Singh, Amrik. 1998. Asia Pacific Tourism Industry: Current Trends and Future Outlook . Asia Pacific Journal of Tourism Research and University of Utah, Salt Lake City, Utah.

[34] Sugiyono. 2004. Administrative Research Methods . Alfabeta, Bandung.

[35] . 2005. Administrative Research Methods . Alfabeta, Bandung.

[36] Sukirno, Sadono. 2006. Economic Development (Process, Problem and Policy Basis). Jakarta: Golden. 
Analysis of Factors Affecting Increased Tourist Visits that Have an Impact on MSME

Development Implications for Job Creation and Regional Revenue in DKI Jakarta

[37] Suryana. 2000. Development Economics . Jakarta: Four Salemba.

[38] Tambunan, TT 2006. The Indonesian Economy, From the Old Order to the Post-Crisis. Quantum Libraries. Jakarta.

[39] PMB-LIPI Research Team. 1998. Socio-Economic and Cultural Potential in the Development of the Tourism Industry. Paper for the Seminar on the Evaluation of a Project for the Study of Strategic Problems in the Political and Socio-Cultural Fields, Indonesian Institute of Sciences, 24 March-26 March 1998.

[40] Todaro, MP 2000. Economic Development in the Third World . Translation: Haris Munandar. Erlangga Publisher. Jakarta.

[41] Vellas, Francois and Becherel, Lionel. 2008. International Tourism Marketing. A Strategic Approach . Obor Indonesia Foundation, Jakarta.

[42] Wahab, S. 2003. Tourism Management . Interpretation of Languages: Drs. Frans Gromang. Fourth Printing.PT.Pradnya Paramita. Jakarta.

[43] Wahana Komputers Professional Series. 2005. Development of Multivatiate Analysis using SPSS 12 . Publisher Salemba Infotek. Jakarta.

[44] Widjaja, HAW. 2002. Regional Autonomy and Autonomous Regions . PT. Raja Grafindo Persada, Jakarta.

[45] Yoeti, Oka A. 2006. Cultural Tourism. Problems and Solutions . Pradnya Paramita, Jakarta.

[46] Yustika, AE2007. Indonesian Economy One Decade Post Economic Crisis . Publishing Agency of the Faculty of Economics, University of Brawijaya (BPFE-Unbraw). Poor.

[47] DKI Jakarta Tourism Office 2008.

[48] Provincial Regulation of the Special Capital Region of Jakarta. Number 10 of 2004 concerning Tourism, DKI Jakarta Tourism Office. www.dki.go.id .

[49] Law of the Republic of Indonesia Number 9 of 1995. Concerning Small Business . Department of Cooperatives and Small Entrepreneur Development.

[50] Law No. 22 of 1999 and Law no. 32 of 2004 concerning Local Government, Jakarta: Sinar Grafika.

[51] Law No. 25 of 1999 and Law no. 33 of 2004 concerning Central and Regional Financial Balance in Jakarta: Sinar Grafika.

[52] Law No. 25 of 2007 concerning Real Sector Investment, Jakarta: Sinar Grafika.

[53] Law N0. 20 of 2008 concerning Micro, Small and Medium Enterprises. Main Media Image. Jakarta.

[54] Law No. 10 of 2009 concerning Tourism . Compiled by: Hadi Setia Tunggal, SH. Harvarindo. Jakarta.

[55] http://www.budpar.go.id . The Ultimate in Diversity Promotional Website.

[56] http://www.antara.co.id . (2007). Tourism Department is preparing "Visit Indonesia Year".

[57] http://www.aseanjournal.com . 